\title{
ON THE EFFECT OF DAY-LENGTH ON THE RATE OF DEVELOPMENT OF SPRING CEREALS
}

\author{
Onni Pohjakallio and Simo Antila \\ Department of Plant Pathology, University of Helsinki
}

Received Juni 11, 1957

The length of the diurnal photoperiod has a great effect on the rate of development of the spring cereal varieties cultivated in Finland (10). Varieties which, when sown at the end of May in conditions of normal long day, ripen as early as August, do not even reach their earing stage by the end of the growing season when the length of the diurnal light-period is shortened to 10 hours. However, in spite of the continuous day prevailing for more than two months in Lapland, the rate of development of the spring cereals is not as rapid there as in South Finland, where the length of the longest day is less than 19 hours $(5,6,7,8)$. The explanation has been advanced that the length of day prevailing in South Finland is already long enough nearly to complete the photoperiodic stimulus. Besides, both the light intensity and the temperature conditions in South Finland are more favourable for a rapid rate of development of spring cereals than in Lapland.

With a view to investigating the part played by light conditions in determining the different rates of development of the spring cereals at different latitudes, numerous workers have employed the method of calculating day-degree summations of the growing period, using as base lines $0^{\circ} \mathrm{C}, 4.4^{\circ} \mathrm{C}\left(=40^{\circ} \mathrm{F}\right)$ or $5^{\circ} \mathrm{C}$, for example; the diurnal mean temperatures above these lines have been added $(2,5)$. Nutronson (5) has preferred the base line of $4.4^{\circ} \mathrm{C}$ to that of $0^{\circ} \mathrm{C}$. However, in view of the vernalizing effect of temperatures between $0^{\circ}$ and $4.4^{\circ} \mathrm{C}$ (or $5^{\circ} \mathrm{C}$, cf. 2) on the late spring cereal varieties (cf. 1, 4), and, in addition, the fact that when the mean temperature of a day is $+5^{\circ} \mathrm{C}$, the temperature at noon may be high enough to promote considerable growth of the spring cereals, we (8) have preferred to add up all mean temperatures above $0^{\circ} \mathrm{C}$.

In different plants the sensitiveness to photoperiod extends to different stages of development (cf. 3). Hence the effect of daylength on the rate of development is easiest to establish if the investigation is restricted to that developmental stage of each plant during which its photoperiodic sensitiveness is a maximum. In the following special attention has been paid to the differences in photoperiodic sensitiveness of spring cereals at their different development stages. In addition, the modifying effect of light intensity on the rate of development of the spring 
cereals has been investigated. Further, an estimation has been made of the relative importance of day-length in the effect of environmental factors on the rate of development of the spring cereals, as revealed by the results of field experiments carried out in 1949 to 1956 , on the one hand at the Viik Experimental Farm, Helsinki $\left(60^{\circ} 10^{\prime} \mathrm{N}\right)$, and, on the other hand, at the Muddusniemi Experimental Farm, Inari $\left(69^{\circ} 5^{\prime} \mathrm{N}\right)$.

The photoperiodic sensitiveness of the spring cereals at their different stages of development was investigated in 1954 to 1956 at Viik, using the field experiment method. The photoperiodic treatments of the spring cereals were started at different dates, and at different developmental stages of the plants. The short diurnal photoperiod (10 hours) was achieved by covering the plants with darkening boxes from 1700 to 0700 (cf. 10). The plant species investigated in 1954 were the spring oat, the spring barley, and the spring wheat. The results obtained from the different spring cereal species proved to be very similar. On account of this fact, only Diamant spring wheat was investigated in the following years. Because of the use of darkening boxes, the plants grown in conditions of short photoperiod were exposed to about $20 \%$ less total light at midsummer, and about $10 \%$ less in autumn than the plants grown in conditions of normal day-length.

The effect of the light conditions on the development of spring cereals was also examined indoors, in two laboratory rooms. The temperature conditions in the two rooms, were the same, - in March $19.1^{\circ} \mathrm{C}$, in April $19.3^{\circ} \mathrm{C}$, in May $22.1^{\circ} \mathrm{C}$, in June $22.9^{\circ} \mathrm{C}$, and in July $23.9^{\circ} \mathrm{C}$, on average. In one of the rooms the plants were exposed to continuous illumination, artificial light (about 1000 lux) being used from 1700 to 0700 . In the other room, the length of the diurnal light period was shortened to 10 hours by the use of darkening curtains. The experiments were carried out with Tammi barley; the experimental pots were Mitscherlich pots. 35 seeds of barley were sown in each pot; after emergence, the number of plants was reduced to 27 . To examine the effect of light intensity, the pots were placed at different distances from the windows (cf. 9).

The rate of development of the spring cereals in the field at the Viik Experimental Farm was compared with that at the Muddusniemi Experimental Farm. The respective temperatures were measured at an altitude of 2 metres above the ground. The diurnal mean temperature was calculated from the temperatures measured at 8 a.m. and 8 p.m. For the calculation of the day-degree summations a base line of $0^{\circ} \mathrm{C}$ was used. In some investigations published earlier $(6,7,8)$, owing to a regrettable mistake, the diurnal mean temperatures have been calculated in a different way at the Viik Experimental Farm and at the Muddusniemi Experimental Farm; on this account the mean temperatures reported for Muddusniemi have been, relatively, somewhat too high.

When the photoperiodic treatment was not started until the wheat had reached the booting stage, the day-length had hardly any effect on the developmental rate of the spring cereals (Table 1). When the photoperiodic treatment was started earlier, 15 to 20 days after emergence, the effect of day-length was very distinct. In the field experiments carried out in 1954, this phenomenon was manifested very similarly in Binder barley, Tammi barley, Guldregn II oat and Diamant wheat. 


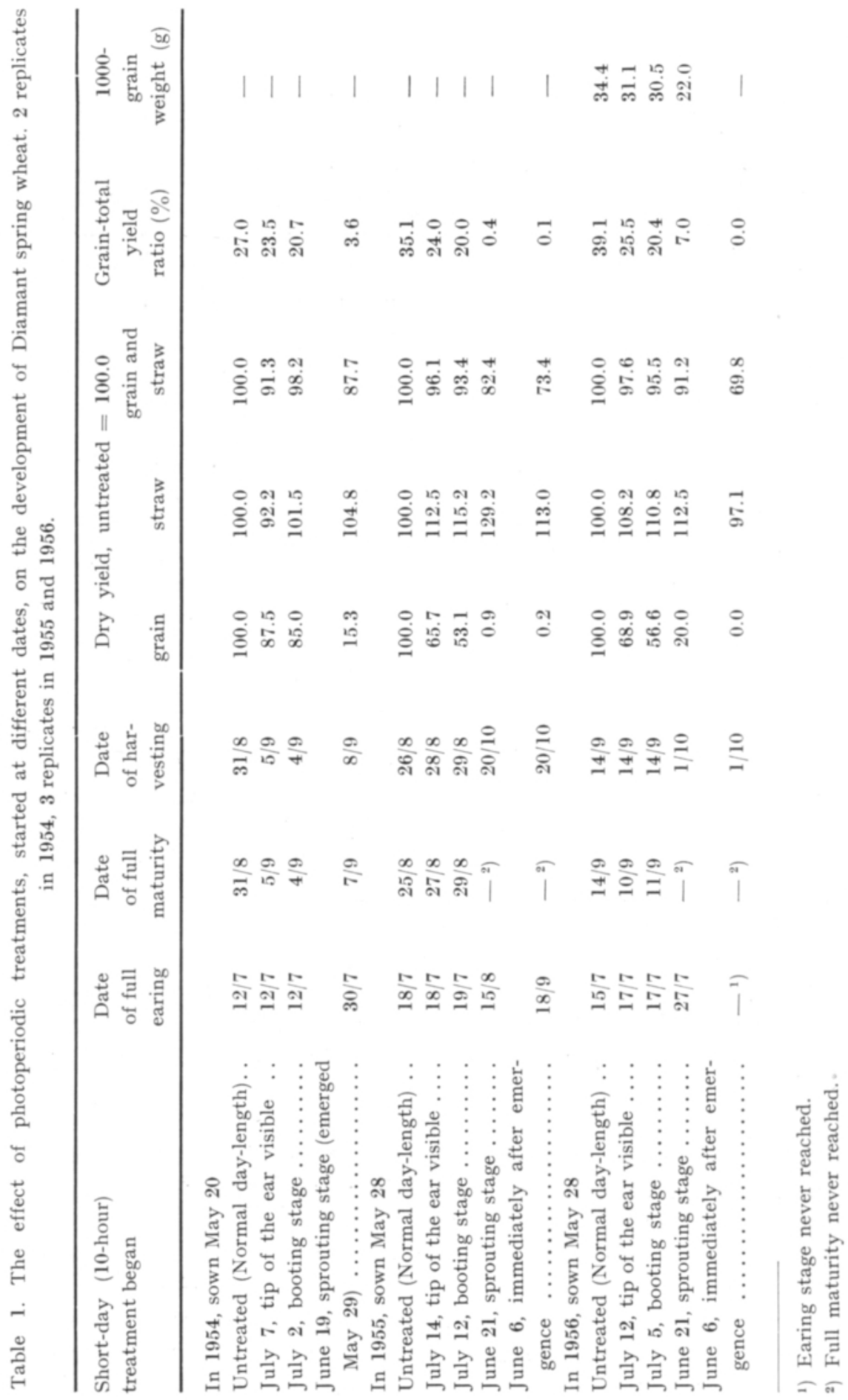




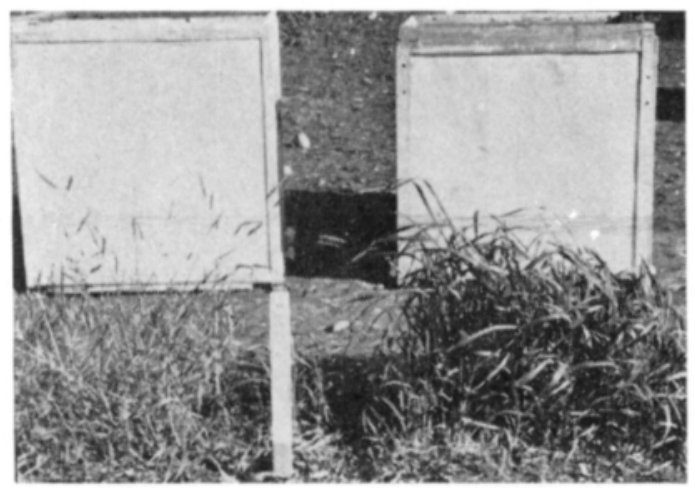

Figure 1. Diamant spring wheat grown in conditions of normal daylength (left), and 10-hour photoperiod (right) at Viik Experimental Farm; September 4, 1956.

When the short-day treatment was started still earlier, or immediately after emergence, the developmental rate of the wheat was greatly retarded (Fig. 1). In the experiments reported earlier (10), the short-day treatment, when started immediately after emergence, retarded the rate of development of Tammi barley less than that of Binder barley, Guldregn II and Diamant wheat. Hence it appears that the visible effect of day-length on the rate of development of spring cereals is restricted to the phase between emergence and the booting stage.

The short-day treatment adversely affected the total yield of the spring cereals, and especially the grain yield. These results were manifested similarly both in the field experiments (Table 1) and in the experiment carried out in the laboratory (Table 2). By contrast, the short photoperiod increased the straw yield. From experiments carried out in the laboratory, however, it is obvious that these results were dependent, in part at least, on the fact that the short-day treatment reduced the total amount of light affecting the plants. Reduction in the light intensity, too, had a very adverse effect on the grain/total yield ratio. The amount of the straw yield was only lower in the conditions of short photoperiod when the plants were exposed, during the daylight period proper, to light intensities lower than $67 \%$ of that prevailing outdoors. Hence it may be concluded that whe $\mathrm{n}$ the spring cereals are exposed to insufficient amounts of light, the utilization of their energy reserves in grain formation is great ly reduced. In the conditions of short photoperiod, the straw yield was also greater owing to the fact that the development of the spring cereals continued longer, in field experiments until the late autumn; in conditions of normal long day, the spring cereals reached full maturity, and hence their growth stopped, much earlier. When the spring cereals were exposed to insufficient amounts of light the number of ears was also relatively small. In the conditions of the short photoperiod, Tammi barley was not able to develop ears at all when exposed to light intensities lower than $46 \%$ of that prevailing outdoors (Table 2). Besides, the deficiency of light delayed the earing rate of Tammi 


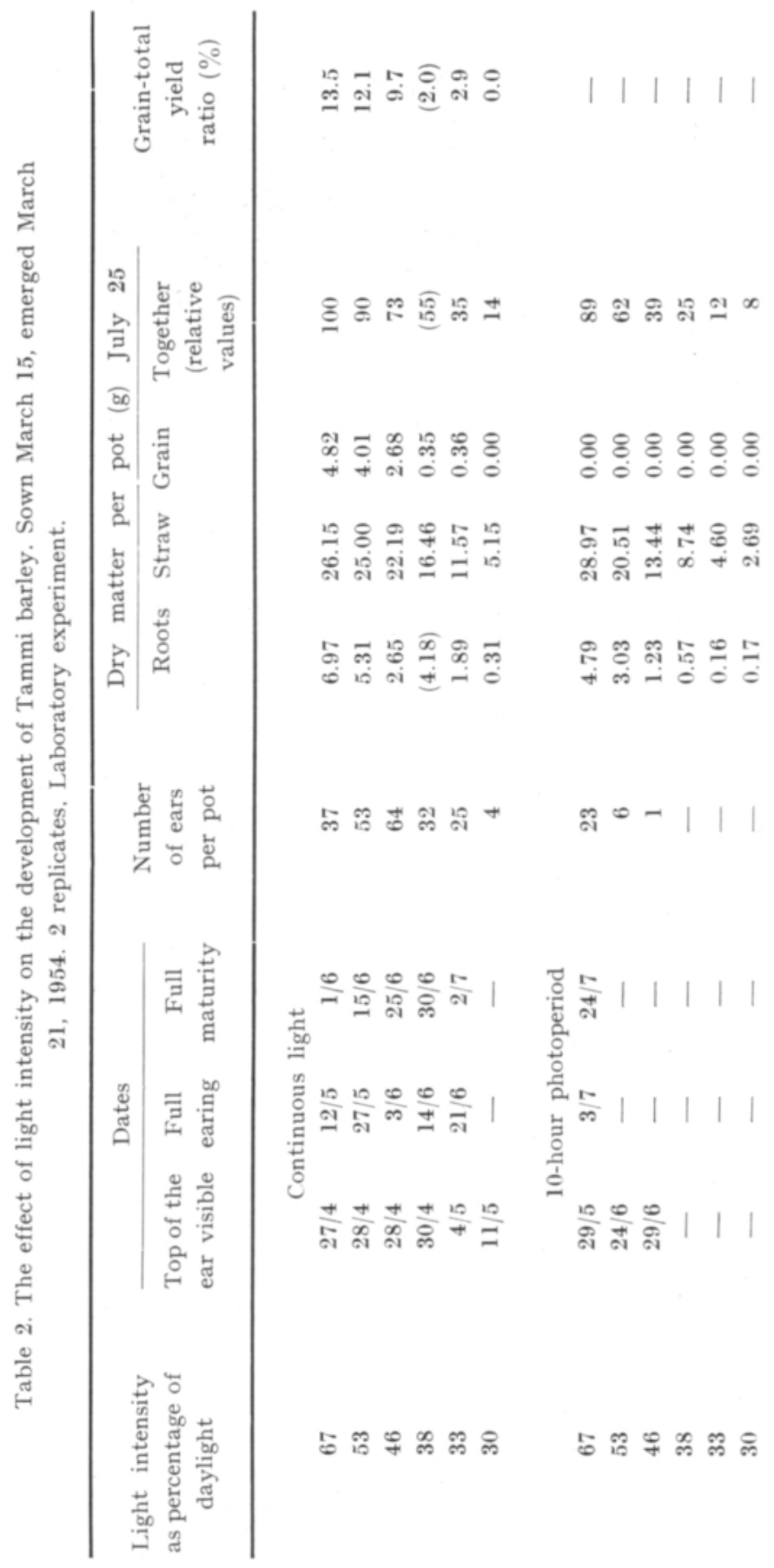




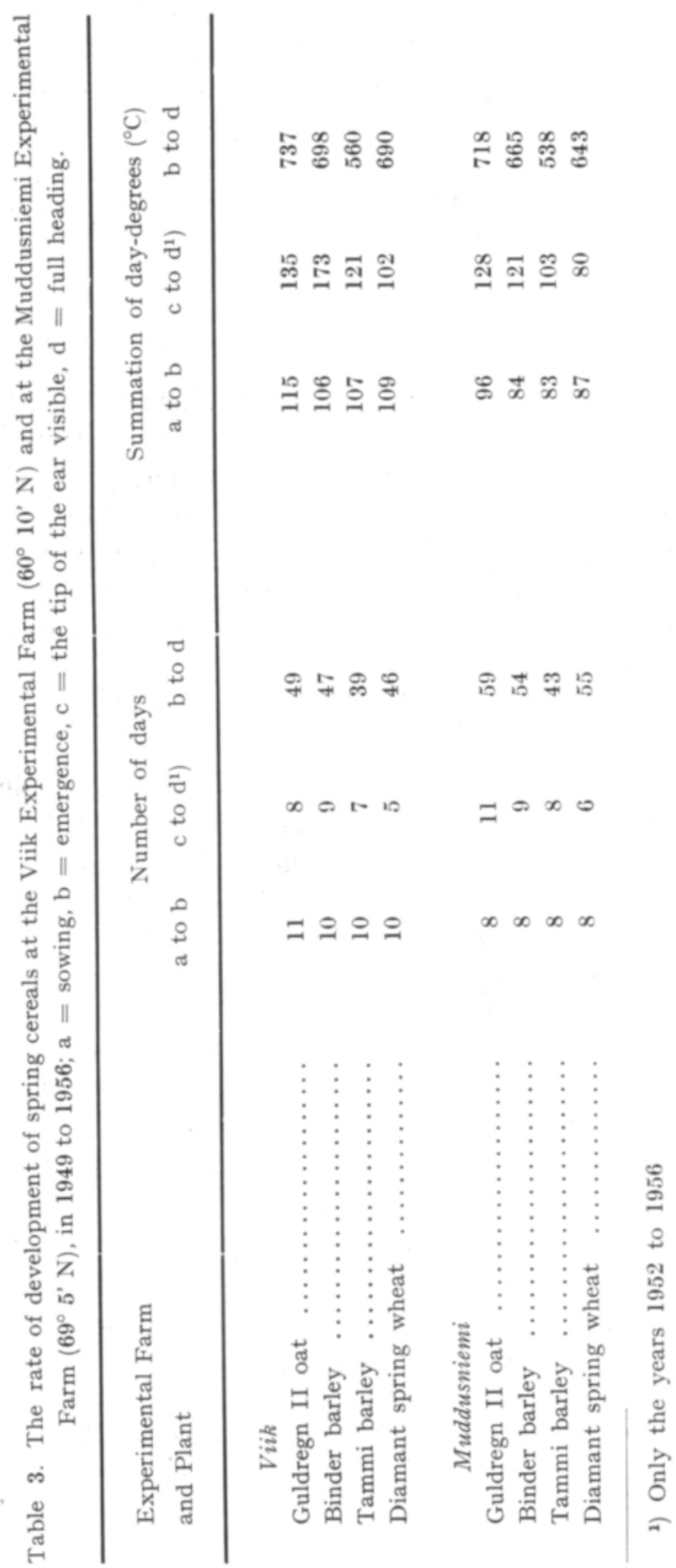


b a rley. This result is in agreement with the experiments carried out earlier (7), when , the plants examined were Binder barley, Guldregn II oat, and Diamant wheat. According to the results of all these experiments, the delaying effect of a deficiency of light on the development of spring cereals manifests itself most clearly during the phase between earing (top of the ear visible) and ripening, i. e., during the stages of development when the spring cereals are hardly at all sensitive to the photoperiodic st i mulus.

At the Muddusniemi Experimental Farm in the years 1949-1956, the grain of even the earliest spring cereal varieties did not reach full maturity. For this reason, the comparisons made between the rates of development of spring cereals at the Viik Experimental Farm and at the Muddusniemi Experimental Farm, have been restricted to cover the developmental phase from sowing to the full earing (Table 3). The rate of development of the spring cereals appeared to be distinctly more rapid at the Viik Experimental Farm $\left(60^{\circ} 10^{\prime} \mathrm{N}\right)$ than at the Muddusniemi Experimental Farm $\left(69^{\circ} 5^{\prime} \mathrm{N}\right)$. However, the day-degree summations over the period from emergence to full heading tend to be higher at Viik than at Muddusniemi. Yet this is true both for the phase of development from sowing to emergence, and for that from the appearance of the tip of the ear to full earing, during which the day-length hardly affects the rate of development of the spring cereals at all. Hence it is evident that some environmental factor other than the photoperiodic effect of long day has proved relatively favourable at Muddusniemi Farm. The first point to suggest itself is that the field soil at Muddusniemi is of fine sand, almost without any humus, i.e., the kind of soil on which spring cereals tend to develop relatively rapidly, whereas at the Viik Experimental Farm, the field soil is of humous loam. When this difference is eliminated, it seems that the effect of the light climate on the rate of the development of spring cereals is nearly equal at Muddusniemi $\left(69^{\circ} 5^{\prime} \mathrm{N}\right)$ and at the Viik Experimental Farm $\left(60^{\circ} 10^{\prime} \mathrm{N}\right)$.

The results of these investigations agree with the earlier view $(6,7,8)$ that within the boundaries of Finland the differences in the length of the summer day even if rather great, have no considerable photoperiodic influence on the rate of development of the spring cereals. It seems, at least, that as far as differences exist within these territorial boundaries in the photoperiodic effects of day-length, the greater amount of light in South Finland (cf. 8) roughly compensates for the longer summer day in North Finland. Thus, the development rate of spring cereals within the boundaries of Finland is primarily determined by t e m per a t u re. In Lapland, where the temperature is lower, the development rate of the spring cereals is perceptibly slower than in South Finland. 
(1) Feistrizer, W. 1934. Die Jarowisation landwirtschaftlicher Kulturpflanzen. Der Züchter 6: 153155.

(2) KERÄNEN, J. 1942. Lämpötalous ja lämpötila maatalousilmastollisina tekijöinä Suomessa (Wärmehaushalt und Temperatur als agrarklimatologische Faktoren in Finnland). Terra 54: $132-151$.

(3) MurneEK, A. E. 1948. History of research in photoperiodism. Vernalization and Photoperiodism by A. E. Murneek and R. O. Whyte: 39-61. Waltham 1948.

(4) Nerling, O. 1933. Die Jarowisation des Getreides nach T. D. Lyssenko. Der Züchter 5: 61-67.

(5) Nutronson, M. Y. 1955. Wheat-climate relationships and the use of phenology in ascertaining the thermal and photo-thermal requirements of wheat. American institute of crop ecology. Washington D.C.

(6) Ронјакаllio, OnNi 1951. Pohjolan kesäpäivän pituuden mahdollisuudesta korvata kasvukauden lyhyys. Luonnon Tutkija 55: 120-124.

(7) $\rightarrow$ 1951. Uber den Einfluss der Umweltfaktoren auf die Dauer der Zeit von der Aussaat bis zum Åhren-(Rispen-)schieben bei Sommergetreide. Soc. Sci. Fenn. Comm. Biol. 11.6.

(8) - 1952. Ljusintensiteten i norra och södra Finland samt dess inverkan på odlingsvăxterna. Nord. jordbr.forskn. 34: 99-112.

(9) - 1954. On the effect of light conditions on the dry matter yield, dry matter content, and root-top ratio of certain cultivated plants. Acta agric. scand. 4: 289-301.

(10) - — \& Salonen, Arvi 1947. Der Einfluss der Tageslänge auf Entwicklung und Energiehaushalt einiger Kulturpflanzen. Acta agr. fenn. 67, 1.

S E L O S T U :

\title{
PÄIVÄN PITUUDEN VAIKUTUKSESTA KEVÄTVILJAN KEHITYKSEN NOPEUTEEN
}

\author{
Onni Pohjakallio ja Simo Antila
}

\section{Helsingin Yliopiston Kasvipatologian laitos}

Päivän pituudella todettiin olevan fotoperiodista vaikutusta kevätviljan kehityksen nopeuteen vain orastumisen ja tupelletulon välisenä aikana. Valon puute on eniten pidentänyt teränteon ja tuleentumisen välistä aikaa, siis sitä kehityksen vaihetta, johon päivän pituudella on tuskin mitään fotoperiodista vaikutusta. Suomen rajojen puitteissa esiintyvillä, sinänsä varsin huomattavilla kesäpäivän pituuseroilla on korkeintaan vähäinen vaikutus kevätviljan kehityksen nopeuteen. Ainakin năyttää siltä, että mikäli näissä aluerajoissa fotoperiodisia vaikutuseroja ilmenee, etelä-Suomen kesäpäivän suurempi valoannos suurin piirtein korvaa pohjois-Suomen kesäpäivän suuremman pituuden. Näin ollen lämpötilan vaikutus jää ratkaisevimmaksi, ja kun lämpötila on Lapissa suhteellisen alhainen, kehittyy kevătvilja siellä jotakuinkin vastaavasti hitaammin kuin etelä-Suomessa.

Lyhyen valojakson olosuhteissa, jolloin valoannos on ollut suhteellisen pieni, ja myös pitkän päivän olosuhteissa, silloin kun valon voimakkuus on ollut vähäinen, jyväsadon osuus viljan koko sadossa on jäänyt verraten pieneksi. 